\title{
Antihypertensive Effect of Piper sarmentosum in L-NAME-Induced Hypertensive Rats
}

(Kesan Antihipertensi Piper sarmentosum pada Tikus Hipertensi Aruhan L-NAME)

\author{
Nik Aloesnisa Nik Mohd Alwi, Zaiton ZaKaria, Aminuddin Abdul Hamid Karim, \\ NOR ANITA MEGAT MOHD NORDIN \& AZIZAH UGUSMAN*
}

\begin{abstract}
Hypertension is one of the risk factors for cardiovascular diseases and has been associated with about $13 \%$ of global deaths worldwide. Oxidative stress and reduced nitric oxide (NO) bioavailability contribute to the development of endothelial dysfunction and subsequently hypertension. $N^{\omega}$-nitro-L-arginine methyl ester hydrochloride (L-NAME) inhibits NO synthesis; leading to hypertension. Piper sarmentosum (PS) is an herb with antioxidant, antiatherosclerosis and antiinflammation properties. PS also stimulated NO production by endothelial cells. The aim of this study was to determine the effects of aqueous extract of Piper sarmentosum (AEPS) on blood pressure, oxidative stress and the level of nitric oxide in L-NAMEinduced hypertensive rats. Hypertension was induced by oral administration of L-NAME $(100 \mathrm{mg} / \mathrm{L})$ in drinking water for four weeks. The rats were concurrently treated with AEPS by oral gavage in serial doses (125, 250 and $500 \mathrm{mg} / \mathrm{kg} / \mathrm{day})$. Blood pressure was measured using non-invasive tail-cuff method at baseline and fortnightly thereafter. Serum level of NO and an oxidative stress marker, malondialdehyde (MDA) were measured at baseline and at the end of treatment. The results showed that treatment with three different doses of AEPS successfully reduced systolic blood pressure $(\mathrm{p}<0.001)$, diastolic blood pressure $(\mathrm{p}<0.05)$ and mean arterial pressure $(\mathrm{p}<0.05)$ in L-NAME-induced hypertensive rats. Treatment with AEPS also reduced MDA level $(\mathrm{p}<0.001)$ and increased serum NO $(\mathrm{p}<0.001)$ in L-NAME-induced hypertensive rats. The findings showed that AEPS decreased blood pressure by protecting against oxidative stress and increasing NO in L-NAME-induced hypertensive rats.
\end{abstract}

Keywords: Hypertension; nitric oxide; $N^{\omega}$-nitro-L-arginine methyl ester hydrochloride; oxidative stress; Piper sarmentosum

\section{ABSTRAK}

Hipertensi merupakan salah satu faktor risiko penyakit kardiovaskular dan ia dikaitkan dengan kira-kira 13\% kematian di seluruh dunia. Stres oksidatif dan pengurangan ketersediaan biologi nitrik oksida (NO) menyumbang kepada terjadinya disfungsi endotelium yang seterusnya menyebabkan hipertensi. $N^{\omega}$-nitro-L-arginina metil ester hidroklorida (L-NAME) merencat sintesis NO dan menyebabkan hipertensi. Piper sarmentosum (PS) adalah herba yang mempunyai sifat antioksidan, antiaterosklerosis dan antiinflamasi. PS juga merangsang pengeluaran NO oleh sel endotelium. Tujuan kajian ini adalah untuk menentukan kesan ekstrak akueus Piper sarmentosum (AEPS) terhadap tekanan darah, stres oksidatif dan aras nitrik oksida dalam tikus hipertensi aruhan L-NAME. Hipertensi diaruh dengan pemberian L-NAME $(100 \mathrm{mg} / \mathrm{L})$ secara oral di dalam air minuman selama empat minggu. Dalam masa yang sama, rawatan tikus dengan AEPS turut diberi serentak melalui gavaj oral dalam dos bersiri (125, 250 dan $500 \mathrm{mg} / \mathrm{kg} / \mathrm{hari})$. Tekanan darah diukur menggunakan kaedah kuf ekor tidak invasif sebelum rawatan dimulakan dan setiap dua minggu selepas itu. Aras serum NO dan penanda stres oksidatif, malondialdehida (MDA) diukur sebelum uji kaji dimulakan dan selepas rawatan tamat. Keputusan menunjukkan rawatan dengan tiga dos AEPS yang berbeza berjaya menurunkan tekanan darah sistolik $(\mathrm{p}<$ $0.001)$, tekanan darah diastolik $(\mathrm{p}<0.05)$ dan tekanan arteri purata $(\mathrm{p}<0.05)$ dalam tikus hipertensi aruhan L-NAME. AEPS juga menurunkan aras MDA $(\mathrm{p}<0.01)$ dan meningkatkan aras $N O(\mathrm{p}<0.001)$ dalam serum tikus hipertensi aruhan L-NAME. Keputusan yang diperoleh menunjukkan bahawa AEPS berupaya menurunkan tekanan darah dengan mengurangkan stres oksidatif dan meningkatkan aras NO pada tikus hipertensi aruhan L-NAME.

Kata kunci: Hipertensi; nitrik oksida; $N^{\infty}$-nitro-L-arginina metil ester hidroklorida; Piper sarmentosum; stres oksidatif

\section{INTRODUCTION}

Hypertension is defined as persistent elevation of systolic blood pressure of $140 \mathrm{mmHg}$ or greater and/or diastolic BP of $90 \mathrm{mmHg}$ or greater. According to World Health Statistic, it was reported that non-communicable diseases (NCD) were mostly caused by cardiovascular diseases
(CVD) which accounted for $31 \%$ of global deaths (Mendis 2014). Hypertension is one of the risk factors for CVD and has been associated with about 17 million deaths annually. It contributes to kidney failure, stroke, heart disease and premature mortality. In the early stage, hypertension is asymptomatic and many people go undiagnosed (WHO2012). 
Endothelial dysfunction (ED) has been observed in the early stage of hypertension and it is the commonest contributing factor to hypertension (Park \& Park 2015). Several studies had suggested that oxidative stress contributed to the development of hypertension through nitric oxide (NO) inactivation (Baradaran et al. 2014; Sinha \& Kumar Dabla 2015). Increased free radical production as well as imbalance between the level of NO and endothelial vasoconstrictors such as endoperoxides, endothelins and thromboxane A lead to endothelial dysfunction and hypertension (Davidge et al. 2015; Panth et al. 2016; Vanhoutte et al. 2017).

Many methods to induce hypertension had been used in animal models. $\mathrm{N}^{\omega}$-nitro-L-arginine methyl ester hydrochloride (L-NAME), an L-arginine analogue, acts as a competitive inhibitor of non-specific nitric oxide synthases (NOS). L-NAME has been widely used to create NO-deficient hypertensive model. It is well established that inhibition of nitric oxide biosynthesis by in vivo administration of L-NAME causes endothelial dysfunction and vasoconstriction, hence leading to hypertension (Raja 2010).

Piper sarmentosum is a herb that had been reported to have antioxidant activity (Hafizah et al.2010). Toxicity studies on aqueous extract of PS showed that the extract is safe for consumption (Mohd Zainudin et al.2013). Previous studies had reported various medicinal effects of PS such as antihyperglycemia (Azlina et al. 2009), antiatherosclerosis (Amran et al. 2010), anticarcinogenesis (Ariffin et al.2009) and antiinflammation (Ridtitid et al. 2007; Zakaria et al. 2010). Apart from that, PS is also able to protect against glucocorticoid-induced osteoporosis (Mohamad Asri et al. 2016) and paracetamol-induced oxidative liver injury (Azlina et al. 2014). Previous studies had shown that PS is able to reduce blood pressure in spontaneously hypertensive rats (SHR) (Zainudin et al. 2015). Aqueous extract of PS is able to stimulate NO production in human umbilical vein endothelial cells (HUVECs) (Ugusman et al. 2012). This suggests that PS may regulate blood pressure via the NO pathway. Therefore, this study was designed to determine the effects of PS on blood pressure, oxidative stress and NO level in L-NAME-induced hypertensive Wistar rats.

\section{MATERIALS AND METHODS}

\section{PLANT MATERIALS}

Fresh leaves of PS were collected in Selayang, Selangor, Malaysia between January to February 2012 and were identified by a plant taxonomist from the Medicinal Plant Division, Forest Research Institute of Malaysia with plant identification number (PID) 170612-11.

\section{PREPARATION OF AQUEOUS EXTRACT} OF PIPER SARMENTOSUM

Aqueous extract of Piper sarmentosum was prepared following the method as reported previously (Mohd
Zainudin et al.2013). Briefly, the leaves of PS were ovendried for $36 \mathrm{~h}$ at $50^{\circ} \mathrm{C}$. Then the dried leaves were cut into small pieces and crushed. $10 \mathrm{~g}$ of dried leaves were mixed with $900 \mathrm{~mL}$ of distilled water. Hot water extraction was prepared by boiling the mixture at $80^{\circ} \mathrm{C}$ for $3 \mathrm{~h}$. Then, the extract was concentrated and freeze-dried into powder form. It was stored at $4^{\circ} \mathrm{C}$ until use.

\section{EXPERIMENTAL ANIMALS}

This study had been approved by the Animal Ethics Committee, Universiti Kebangsaan Malaysia (approval code: PP/FISIO/2011/AMINUDDIN/22-MARCH/360-JUNE2011-JUNE-2012). Healthy adult male Wistar rats, aged 6 to 8 weeks, weighing between 170-220 g were obtained from the Laboratory Animal Resource Unit, Universiti Kebangsaan Malaysia. The rats were maintained in an air-conditioned room at $23 \pm 3^{\circ} \mathrm{C}$ and were housed in individual cages with a 12 -h light and 12-h dark cycle. The rats were provided with normal rat chow and clean drinking water ad libitum. The rats were acclimatized for one week before the experiment started.

\section{EXPERIMENTAL DESIGN AND INDUCTION OF HYPERTENSION}

Thirty six animals were divided into six groups with six animals in each group ( $n=6)$ : control group; Aqueous extract Piper sarmentosum (AEPS) only group where the rats were given $500 \mathrm{mg} / \mathrm{kg} /$ day AEPS via oral gavage; L-NAME-induced hypertensive group was given $100 \mathrm{mg} / \mathrm{L}$ L-NAME in drinking water and three groups of L-NAMEinduced-hypertensive rats with co-treatment of different doses of AEPS; $100 \mathrm{mg} / \mathrm{LL}-\mathrm{NAME}$ and $125 \mathrm{mg} / \mathrm{kg} /$ day AEPS; $100 \mathrm{mg} / \mathrm{L} \mathrm{L}-\mathrm{NAME}$ and $250 \mathrm{mg} / \mathrm{kg} /$ day AEPS; and $100 \mathrm{mg} / \mathrm{L}$ L-NAME and $500 \mathrm{mg} / \mathrm{kg} /$ day AEPS. The treatments were given for four weeks (Wheal et al. 2007). Group 2 was included in this study to investigate whether AEPS on its own could affect the parameters measured in this study. All the three doses of AEPS were adopted from previous study on anti-atherosclerosis effect of AEPS (Amran et al.2010).

\section{DETERMINATION OF BLOOD PRESSURE}

Systolic blood pressure (SBP), diastolic blood pressure (DBP) and mean arterial pressure (MAP) were measured in non-anaesthetized rats by non-invasive tail-cuff CODA blood pressure system (Kent Scientific Corporation, USA) at baseline and every two weeks after starting treatment (Zainudin et al.2015). At least five readings were recorded during each measurement. The maximum and minimum values were discarded and the remaining three values were calculated as the average (Si \& Liu 2008; Yang et al. 2008).

\section{BLOOD SAMPLES COLLECTION}

Blood samples $(2 \mathrm{~mL})$ were obtained in the morning at baseline and at the end of four weeks treatment via retro orbital sinus puncture with the animal under the 
combination anaesthesia of Zoletil, Xylazil and Ketamine and were collected in plain tubes. The blood samples were centrifuged at $3000 \mathrm{rpm}$ for $10 \mathrm{~min}$ to obtain the serum. After the separation, the serum was aspirated and was frozen at $-80^{\circ} \mathrm{C}$ until further experiments.

\section{DETERMINATION OF NITRIC OXIDE LEVEL}

Since nitric oxide is unstable in aqueous condition and has a short half-life, the level of its stable metabolites, nitrite $\left(\mathrm{NO}_{2}^{-}\right)$and nitrate $\left(\mathrm{NO}_{3}^{-}\right)$was measured based on Griess method using QuantiChrom ${ }^{\mathrm{TM}}$ nitric oxide assay kit (BioAssay Systems, USA) according to the manufacturer's instructions. Total $\mathrm{NO}_{2}{ }^{-} / \mathrm{NO}_{3}{ }^{-}$in the serum samples were quantitated by measuring the optical density at $540 \mathrm{~nm}$.

\section{DETERMINATION OF PLASMA MALONDIALDEHYDE (MDA)}

The lipid peroxidation indicator, plasma MDA was measured using thiobarbituric acid reactive substances (TBARS) assay as described previously (Borges et al. 2018). Total protein concentration in the serum was measured using protein biuret reaction (Pessoa et al. 2017). Plasma MDA level was calculated based on the following formula:

$$
\underline{\text { OD sample }} \times \underset{\text { standard }}{\text { OD stand }} \times \underset{\text { Total volume }}{\times}
$$

Plasma level of MDA was expressed as nmol/g protein

\section{STATISTICAL ANALYSIS}

All statistical analysis was conducted using IBM SPSS Statistic version 22.0. The data were expressed as mean \pm SEM. SBP, DBP and MAP results were analysed using oneway analysis of variance (ANOVA) with Tukey post-hoc test while serum nitric oxide and malondialdehyde level were analysed using paired t-test. $P<0.05$ was considered statistically significant.

\section{RESULTS}

\section{EFFECT OF AEPS ON SYSTOLIC BLOOD PRESSURE}

At baseline, there was no significant difference in SBP among the groups. Following two weeks of treatment, L-NAME-induced rats had higher SBP $(155.3 \pm 2.14 \mathrm{mmHg})$ compared to control rats $(121.8 \pm 0.60 \mathrm{mmHg})(p<0.001)$. Treatment of L-NAME-induced rats with all three doses of AEPS $(125,250$ and $500 \mathrm{mg} / \mathrm{kg} /$ day) successfully reduced SBP to normal level $(128.0 \pm 4.37,127.8 \pm 5.19$ and $122.17 \pm 4.48 \mathrm{mmHg}$, respectively) $(p<0.001)$. At the end of four weeks treatment, the SBP of L-NAME-induced rats were persistently high compared to control (172.3 \pm 5.06 vs. $116.7 \pm 1.52 \mathrm{mmHg}, p<0.001)$. Treatment with all three doses of AEPS significantly attenuated L-NAMEinduced rise in SBP at the end of treatment (126.0 \pm 5.2 , $127.83 \pm 3.79$ and $129.67 \pm 3.74 \mathrm{mmHg}$, respectively) $(p<0.001)$. However, there was no significant difference in SBP between the three doses of AEPS following two and four weeks of treatment. In addition, administration of AEPS alone did not significantly alter the SBP compared to control.

\section{EFFECT OF AEPS ON DIASTOLIC BLOOD PRESSURE}

At baseline, there was no significant difference in DBP among the groups. Following two weeks of treatment, L-NAME-induced rats had higher DBP $(112.2 \pm 3.25 \mathrm{mmHg})$ compared to control rats $(83.6 \pm 1.23 \mathrm{mmHg})(p<0.01)$. Treatment of L-NAME-induced rats with three doses of AEPS $(125,250$ and $500 \mathrm{mg} / \mathrm{kg} /$ day $)$ successfully reduced $\operatorname{DBP}(94.0 \pm 5.41,87.0 \pm 4.97$ and $86.3 \pm 8.2 \mathrm{mmHg})(p<$ $0.05)$. At the end of the four weeks treatment, the DBP of L-NAME-induced rats were persistently high compared to control $(127.5 \pm 3.93$ vs. $78.8 \pm 2.41 \mathrm{mmHg}, p<0.01)$. Treatment of L-NAME-induced rats with all three doses of AEPS significantly reduced DBP to normal level at the end of treatment $(84.5 \pm 4.38,90.0 \pm 2.44$, and $86.3 \pm$ $4.19 \mathrm{mmHg}$, respectively) $(p<0.05)$. However, there was

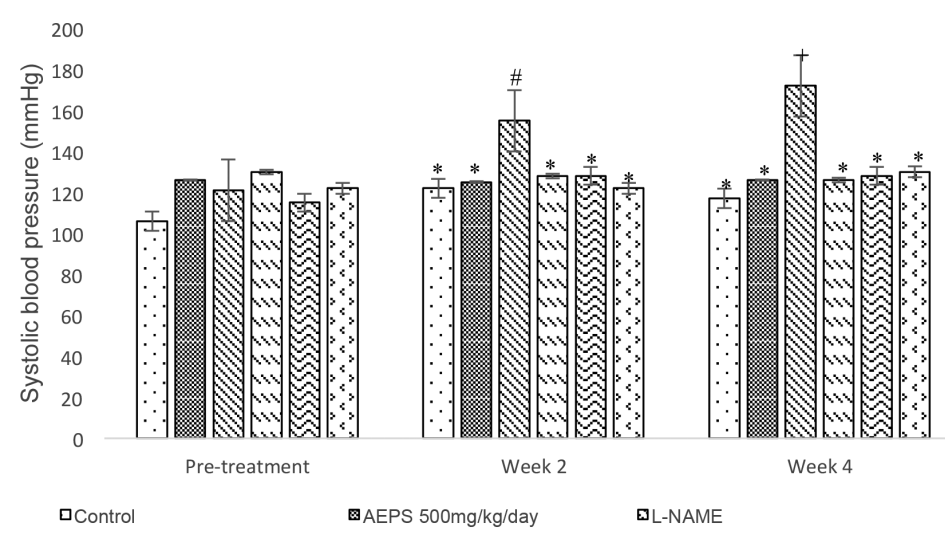

${ }^{*} p<0.001$ versus L-NAME group within the same week, $\# p<0.001$ versus pre-treatment group

FIGURE 1. Effect of AEPS on systolic blood pressure (SBP) in L-NAME induced hypertensive rats 


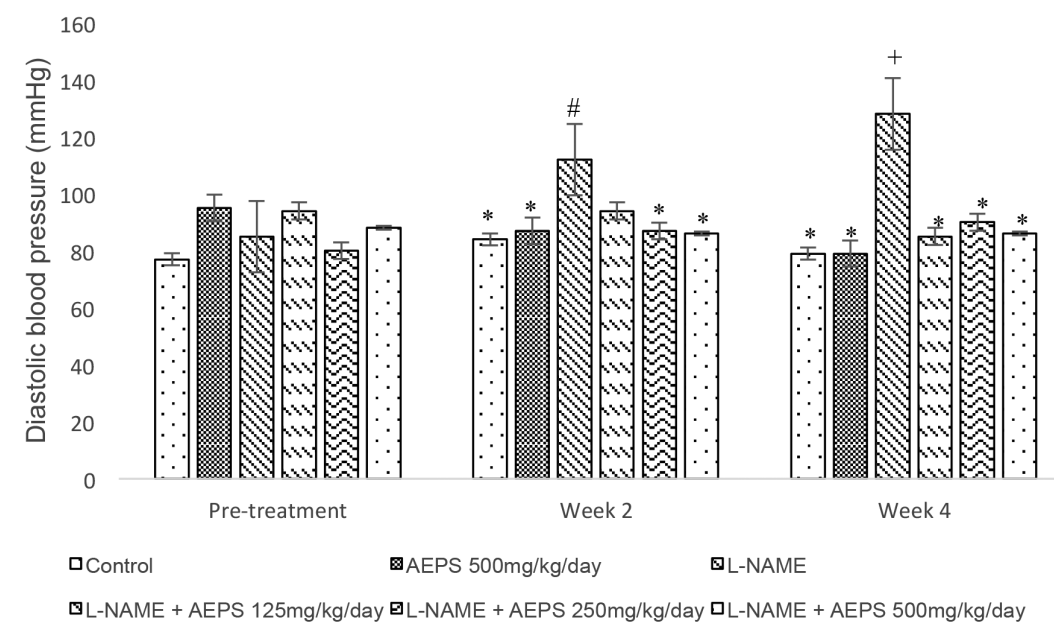

${ }_{p} p<0.05$ versus L-NAME within the same week, " $p<0.01$ versus pre-treatment group

FIGURE 2. Effect of AEPS on diastolic blood pressure (DBP) in L-NAME induced hypertensive rats

no significant difference in DBP between the three doses of AEPS following two and four weeks of treatment. In addition, administration of AEPS alone did not significantly alter the DBP compared to control.

\section{EFFECT OF AEPS ON MEAN ARTERIAL BLOOD PRESSURE}

The changes in MAP were in accordance to changes in SBP and DBP. At baseline, there was no significant difference in MAP among the groups. Following two weeks of treatment, L-NAME-induced rats had higher MAP $(126.0 \pm 2.45 \mathrm{mmHg})$ as compared to control rats $(96.7 \pm 0.88 \mathrm{mmHg})(p<0.05)$. Treatment of L-NAME-induced rats with all three doses of AEPS successfully reduced MAP $(104.7 \pm 4.97,98.8 \pm 3.93$ and $97.8 \pm 6.89 \mathrm{mmHg})(p<0.05)$. At the end of the four weeks treatment, the MAP of L-NAME-induced rats were persistently high compared to control $(142.0 \pm 4.49 \mathrm{vs} .91 .2$ $\pm 1.78 \mathrm{mmHg}, p<0.05)$. Treatment of L-NAME-induced rats with all three doses of AEPS significantly reduced MAP at the end of treatment $(97.0 \pm 3.44,101.2 \pm 1.86$ and 100.5 $\pm 2.71 \mathrm{mmHg}$, respectively) $(p<0.05)$. However, there was no significant difference in MAP between the three doses of AEPS following two and four weeks of treatment. In addition, administration of AEPS alone did not significantly alter the MAP compared to control.

\section{EFFECTS OF AEPS ON SERUM NO}

L-NAME induction caused reduction of serum NO compared to its pre-induction level $(4.5 \pm 1.92$ vs $40.7 \pm 6.26$ $\mu \mathrm{M}, p<0.05)$ as well as compared to control $(p<0.001)$. Treatment with all three doses of AEPS $(125,250,500 \mathrm{mg} /$ $\mathrm{kg} /$ day) increased serum NO compared to L-NAME group $(p<0.001)$ with the values of $56.33 \pm 9.15,80.88 \pm 8.55$ and $75.02 \pm 8.46 \mu \mathrm{M}$, respectively. Apart from that, there was significant difference in the level of NO before and after treatment in AEPS, L-NAME + AEPS $250 \mathrm{mg} / \mathrm{kg} /$ day and L-NAME + AEPS $500 \mathrm{mg} / \mathrm{kg} /$ day groups $(p<0.05)$.

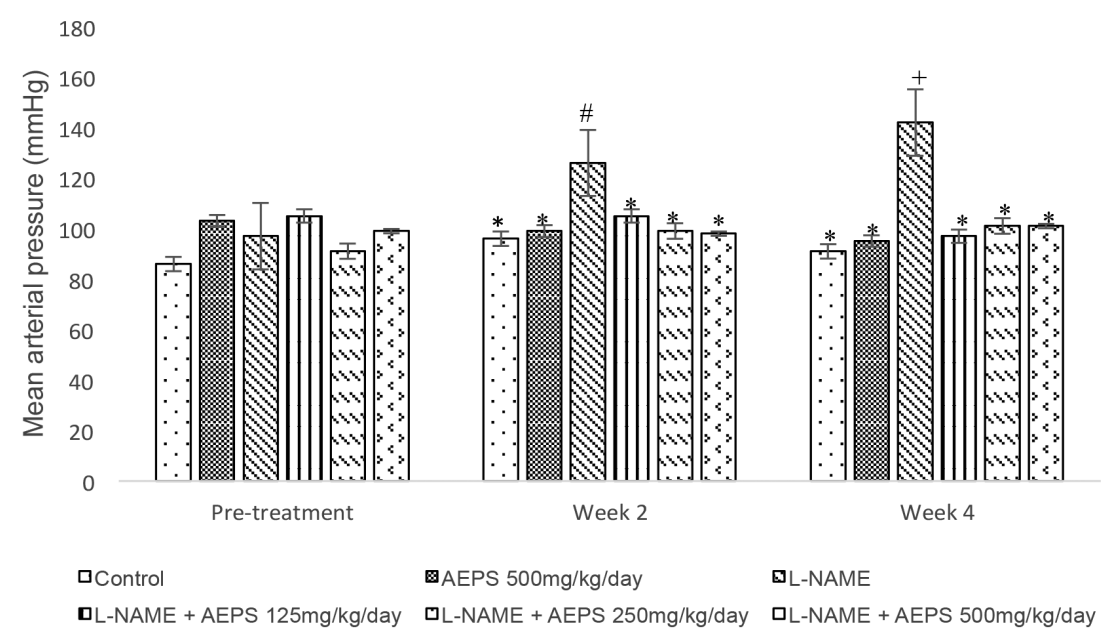

${ }^{*} p<0.05$ vs L-NAME within the same week, ${ }^{*} p<0.05$ vs pre-treatment group

FIGURE 3. Effect of AEPS on mean arterial pressure (MAP) in L-NAME induced hypertensive rats 


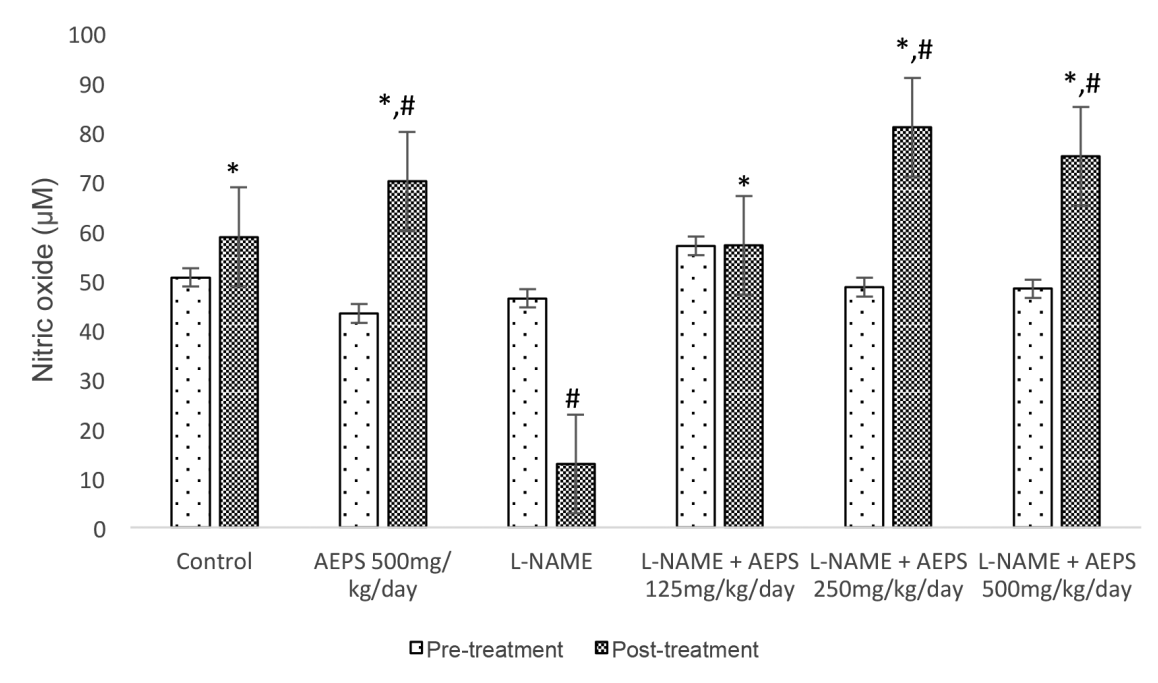

${ }^{*} p<0.001$ versus L-NAME, $\# p<0.05$ versus pre-treatment

FIGURE 4. Effect of AEPS on serum NO in L-NAME- induced-hypertensive rats

\section{EFFECT OF AEPS ON SERUM MDA}

Four weeks following L-NAME induction, serum MDA was increased compared to its pre-induction level (65.59 \pm $5.46 \mathrm{vs} .23 .81 \pm 4.33 \mathrm{nmol} / \mathrm{g}$ protein, $p<0.01)$ as well as compared to control $(p<0.05)$. Treatment with all three doses of AEPS $(125,250,500 \mathrm{mg} / \mathrm{kg} /$ day $)$ reduced serum MDA level compared to L-NAME group $(p<0.05)$ with the values of $22.70 \pm 3.63,16.57 \pm 4.64$ and $25.15 \pm 11.39$ $\mathrm{nmol} / \mathrm{g}$ protein, respectively.

\section{DISCUSSION}

Hypertension is categorized into primary or essential hypertension (EH) and secondary hypertension. More than $90 \%$ of hypertensive patients have $\mathrm{EH}$ whereby the cause is still unclear. Current studies suggest that NO deficiency contributes to EH (Arora et al. 2009). Increased in free radical generation inactivates prostacyclin and $\mathrm{NO}$, hence causing half-life of prostacyclin and NO to be decreased. This situation may lead to increase in peripheral vascular resistance and subsequently hypertension (Kumar \& Das 1993). Basal production of NO was reduced in spontaneously hypertensive rats (SHR) (Dohi et al. 1990). The endothelium-dependant vasodilator responses were attenuated in patients who suffered from essential hypertension which was mainly contributed to reduced bioactivity of NO (Panza et al. 1990).

The main objective in this study was to evaluate whether the high blood pressure in NO-deficient hypertensive rats induced by L-NAME, an L-arginine analogue that inhibits nitric oxide synthases could be improved by AEPS treatment. In the present study, the administration

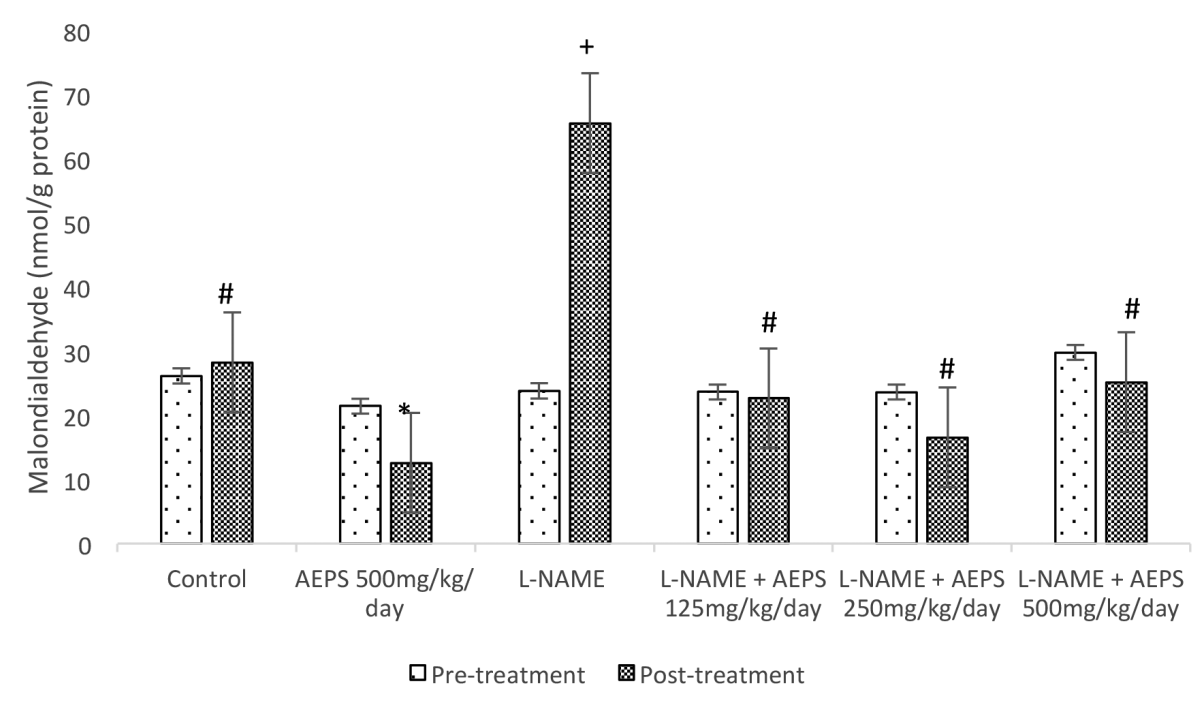

${ }^{*} p<0.001$ vs L-NAME; ${ }^{*} p<0.05$ vs L-NAME; ${ }^{+} p<0.01$ vs pre-treatment

FIGURE 5. Effect of AEPS on serum MDA level in L-NAME induced-hypertensive rats 
of L-NAME in drinking water had induced hypertension in rats which concurred with previous studies (Raja 2010). Concomitant treatment with serial doses of AEPS in the L-NAME-induced hypertensive rats had significantly attenuated the hypertension.

Nitric oxide produced by endothelial nitric oxide synthase (eNOS) is the major source of circulating NO. L-NAME interferes with the activity of eNOS, thus reducing NO production (Raja 2010). Since NO is a potent vasodilator, decreased NO production may impair endothelial-dependent vasodilation, causing increased peripheral resistance and blood pressure (Park \& Park 2015). Previous study had proven that PS increased NO level by stimulating eNOS expression and activity in HUVECS (Ugusman et al. 2010). Therefore, increased level of NO in L-NAME-induced hypertensive rats treated with AEPS could be due to increase in the activity of eNOS. A study by Ugusman et al. (2014) had found that a flavonoid, rutin, one of the compound in Piper sarmentosum, may improve endothelial function by augmenting NO production in HUVEC. Another recent study on PS showed that the extract was able to reduce blood pressure by increasing NO production in SHR (Zainudin et al. 2015).

Apart from inhibiting NO synthesis, L-NAME induces hypertension by causing oxidative stress. L-NAME is responsible to cause imbalance in renin-angiotensin system (RAS) whereby it increased the expression of angiotensin II and also caused renal dysfunction (Rincon et al. 2015). The excessive production of angiotensin II leads to increase vascular superoxide $\left(\mathrm{O}_{2}^{-}\right)$formation through increased expression of NADPH-dependent oxidase in aortic smooth muscle cells (Tsai et al. 2016). The excessive $\mathrm{O}_{2}^{-}$react rapidly with $\mathrm{NO}$ to form peroxynitrite $\left(\mathrm{ONOO}^{-}\right)$. Peroxynitrite is a strong pro-oxidant molecule which causes lipid peroxidation and tissue injury (Hogg et al. 2017). In addition, hypertension itself leads to enhanced production of ROS. Previous studies had shown that in different models of systemic hypertension, there would be enhancement of $\mathrm{O}_{2}^{-}$and superoxide-producing enzymes, regardless of how the hypertension was induced (Drummond \& Sobey 2014; García-Redondo et al. 2016). Malondialdehyde exists in the serum, plasma, tissues as well as in the urine. It is the commonest analytic estimation of lipid peroxidation and oxidative stress that has been reported (Chen et al. 2015). In the present study, the level of MDA was increased in the L-NAME-induced hypertensive rats; indicating that oxidative stress plays an important role in the pathophysiology of hypertension (Baradaran et al. 2014). Treatment of L-NAME-induced hypertensive rats with AEPS caused reduction in MDA level. This finding is in accordance to a recent study which showed that PS significantly reduced MDA level in spontaneously hypertensive rats (Zainudin et al. 2015).

Decreased level of MDA in AEPS treated group could be attributed to the antioxidant effects of PS. PS had been proven to have strong antioxidant activity (Ugusman et al. 2012). Besides, PS had been shown to suppress intercellular adhesion molecule-1 (ICAM-1) and NADPH oxidase 4
(Nox4) expressions in oxidative stress-induced HUVECs. Nox 4 is the predominant enzyme for ROS production in endothelial cells (Ugusman et al. 2010). Several chemical compounds with antioxidant activities found in PS are polyphenols, vitamins $\mathrm{C}$ and $\mathrm{E}$, carotenes, tannins, xanthophylls, flavonoids and amides (Hussain et al. 2015). Polyphenols had been shown to reduce blood pressure in NO-deficient model of hypertension (Bernátová et al. 2002; Rodrigo et al. 2016). Since this study used crude extract of PS and not its isolated bioactive components, this study was unable to specify the active compound responsible for the antihypertensive effect. However, it is suggested that the antihypertensive effect of PS in NO-deficient model of hypertension observed in this study is due to its polyphenols content.

\section{CONCLUSION}

AEPS reduces blood pressure in L-NAME-induced hypertensive rats and the antihypertensive effect may be partly mediated by increased NO and reduced oxidative stress. Our findings suggest that AEPS has the potential to be developed as a therapeutic agent for hypertension. However, further studies using isolated bioactive components from AEPS are required in order to support the therapeutic potential of AEPS for hypertension.

\section{ACKNOWLEDGEMENTS}

This study was funded by UKMMC Fundamental Research Fund (FF-174-2011). The authors express their sincere thanks to the staff of Physiology Department; Norizam Salamt, Fadzilah Mohd Suratman, Zanariyah Asmawi, Musmarlina Omar, Aini Farzana Zulkefli and Kamariah Othman for the technical assistance.

\section{REFERENCES}

Amran, A.A., Zakaria, Z., Othman, F., Das, S., Raj, S.\& Nordin, N.A.M. 2010. Aqueous extract of Piper sarmentosum decreases atherosclerotic lesions in high cholesterolemic experimental rabbits. Lipids in Health and Disease 9: 44.

Ariffin, S.H.Z., Omar, W.H.H.W., Ariffin, Z.Z., Safian, M.F., Senafi, S. \& Wahab, R.M.A. 2009. Intrinsic anticarcinogenic effects of Piper sarmentosum ethanolic extract on a human hepatoma cell line. Cancer Cell International 9: 6.

Arora, S., Das, N. \& Srivastava, K. 2009. Nitric oxide and eNOS gene in essential hypertension. International Journal of Collaborative Research on Internal Medicine and Public Health (IJCRIMPH) 1: 56-71.

Azlina, A.A., Farihah, H., Qodriyah, H. \& Nur, A. 2009. Effects of Piper sarmentosum water extract on 11- $\beta$ hydroxysteroid dehydrogenase Type 1 bioactivity in ovariectomy-induced obese rats. IJP-International Journal of Pharmacology 5: 362-369.

Azlina, M., Qodriyah, H., Hamizah, A. \& Kamisah, Y. 2014. Effects of methanolic extract of Piper sarmentosum on paracetamol-induced hepatic oxidative injury in rats. Sains Malaysiana 43(3): 415-421.

Baradaran, A., Nasri, H. \& Rafieian-Kopaei, M. 2014. Oxidative stress and hypertension: Possibility of hypertension therapy 
with antioxidants. Journal of Research in Medical Sciences: The Official Journal of Isfahan University of Medical Sciences 19(4): 358-367.

Bernátová, I., Pechánová, O., Babál, P., Kyselá, S., Stvrtina, S. \& Andriantsitohaina, R. 2002. Wine polyphenols improve cardiovascular remodeling and vascular function in NOdeficient hypertension. American Journal of PhysiologyHeart and Circulatory Physiology 282: H942-H948.

Borges, A., Piassão, J., Paula, M., Sepp, S., Bez, C., Hepp, L., Valduga, A., Pereira, A. \& Cansian, R. 2018. Characterization of oxidative stress biomarkers in a freshwater anomuran crab. Brazilian Journal of Biology 78: 61-67.

Chen, J., Zeng, L., Xia, T., Li, S., Yan, T., Wu, S., Qiu, G. \& Liu, Z. 2015. Toward a biomarker of oxidative stress: A fluorescent probe for exogenous and endogenous malondialdehyde in living cells. Analytical Chemistry 87: 8052-8056.

Davidge, S.T., de Groot, C.J. \& Taylor, R.N. 2015. Endothelial cell dysfunction. Chesley's Hypertensive Disorders in Pregnancy (4th ed.) Elsevier. pp. 181-207.

Dohi, Y., Thiel, M.A., Bühler, F. \& Lüscher, T. 1990. Activation of endothelial L-arginine pathway in resistance arteries. Effect of age and hypertension. Hypertension 16: 170-179.

Drummond, G.R. \& Sobey, C.G. 2014. Endothelial NADPH oxidases: Which NOX to target in vascular disease? Trends in Endocrinology \& Metabolism 25: 452-463.

García-Redondo, A.B., Aguado, A., Briones, A.M. \& Salaices, M. 2016. NADPH oxidases and vascular remodeling in cardiovascular diseases. Pharmacological Research 114: $110-120$.

Hafizah, A.H., Zaiton, Z., Zulkhairi, A., Ilham, A.M., Anita, M.M.N.N. \& Zaleha, A.M. 2010. Piper sarmentosum as an antioxidant on oxidative stress in human umbilical vein endothelial cells induced by hydrogen peroxide. Journal of Zhejiang University SCIENCE B 11: 357-365.

Hogg, N., Zielonka, J. \& Kalyanaraman, B. 2017. Detection of nitric oxide and peroxynitrite in biological systems: A stateof-the-art review. Nitric Oxide. 3rd ed. Elsevier. pp. 23-44.

Hussain, K., Ismail,Z., Sadikun, A., Ibrahim, P. \& Malik, A. 2015. In vitro antiangiogenesis activity of standardized extracts of Piper sarmentosum roxb. Jurnal Riset Kimia 1: 146.

Kumar, K.V. \& Das, U. 1993. Are free radicals involved in the pathobiology of human essential hypertension? Free Radical Research 19: 59-66.

Mendis, S. 2014. Global Status Report on Noncommunicable Diseases 2014. World Health Organization.

Mohamad Asri, S.F., Mohd Ramli, E.S., Soelaiman, I.N., Mat Noh, M.A., Abdul Rashid, A.H. \& Suhaimi, F. 2016. Piper sarmentosum effects on $11 \beta$-Hydroxysteroid dehydrogenase type 1 enzyme in serum and bone in rat model of glucocorticoid-induced osteoporosis. Molecules 21(11): 1523.

Mohd Zainudin, M., Zakaria, Z., Nordin, M.M., Anita, N. \& Othman, F. 2013. Does oral ingestion of Piper sarmentosum cause toxicity in experimental animals? Evidence-Based Complementary and Alternative Medicine 2013: 705950.

Panth, N., Paudel, K.R. \& Parajuli, K. 2016. Reactive oxygen species: A key hallmark of cardiovascular disease. Advances in Medicine 2016: 9152732.

Panza, J.A., Quyyumi, A.A., Brush Jr, J.E. \& Epstein, S.E. 1990. Abnormal endothelium-dependent vascular relaxation in patients with essential hypertension. New England Journal of Medicine 323: 22-27.
Park, K.H. \& Park, W.J. 2015. Endothelial dysfunction: Clinical implications in cardiovascular disease and therapeutic approaches. Journal of Korean Medical Science 30: 12131225.

Pessoa, L.M.B., Lima, M.G.d.M., Carneiro, F.T., Zanani, N.S., Scalon, M.C., Silva, T.F., Lima, M.A., Abrahim, M.A \& Paludo, G.R. 2017. Refractometry as an alternative to the biuret method for measuring total serum proteins in Podocnemis expansa (Podocnemididae) and Phrynops geoffroanus (Chelidae). Acta Amazonica 47: 83-86.

Raja, B. 2010. Antihypertensive and antioxidant potential of borneol-a natural terpene in L-NAME-induced hypertensive rats. International Journal of Pharmaceutical \& Biological Archive 1: 271-279.

Ridtitid, W., Ruangsang, P., Reanmongkol, W. \& Wongnawa, M. 2007. Studies of the anti-inflammatory and antipyretic activities of the methanolic extract of Piper sarmentosum Roxb. leaves in rats. Songklanakarin Journal of Science \& Technology 29: 1519-1526.

Rincon, J., Correia, D., Arcaya, J., Finol, E., Fernández, A., Pérez, M., Yaguas, K., Talavera, E., Chávez, M. \& Summer, R. 2015. Role of angiotensin II type 1 receptor on renal NAD (P) H oxidase, oxidative stress and inflammation in nitric oxide inhibition induced-hypertension. Life Sciences 124: 81-90.

Rodrigo, R., Brito, R. \& González, J. 2016. Oxidative stress and essential hypertension. In Update on Essential Hypertension. InTech.

Si, H. \& Liu, D. 2008. Genistein, a soy phytoestrogen, upregulates the expression of human endothelial nitric oxide synthase and lowers blood pressure in spontaneously hypertensive rats. The Journal of Nutrition 138: 297-304.

Sinha, N. \& Kumar Dabla, P. 2015. Oxidative stress and antioxidants in hypertension - A current review. Current Hypertension Reviews 11: 132-142.

Tsai, I.C., Pan, Z.C., Cheng, H.P., Liu, C.H., Lin, B.T. \& Jiang, M.J. 2016. Reactive oxygen species derived from NADPH oxidase 1 and mitochondria mediate angiotensin II-induced smooth muscle cell senescence. Journal of Molecular and Cellular Cardiology 98: 18-27.

Ugusman, A., Zakaria, Z., Chua, K.H., Nordin, M.M., Anita, N \& Abdullah Mahdy, Z. 2014. Role of rutin on nitric oxide synthesis in human umbilical vein endothelial cells. The Scientific World Journal 2014: 169370.

Ugusman, A., Zakaria, Z., Hui, C.K., Nordin, N.A.M.M. \& Mahdy, Z.A. 2012. Flavonoids of Piper sarmentosum and its cytoprotective effects against oxidative stress. EXCLI Journal 11: 705.

Ugusman, A., Zakaria, Z., Hui, C.K. \& Nordin, N.A.M.M. 2010 Piper sarmentosum increases nitric oxide production in oxidative stress: A study on human umbilical vein endothelial cells. Clinics 65: 709-714.

Vanhoutte, P., Shimokawa, H., Feletou, M. \& Tang, E. 2017. Endothelial dysfunction and vascular disease - a 30th anniversary update. Acta Physiologica 219: 22-96.

Wheal, A., Bennett, T., Randall, M. \& Gardiner, S. 2007. Effects of chronic nitric oxide synthase inhibition on the cardiovascular responses to cannabinoids in vivo and in vitro. British Journal of Pharmacology 150: 662-671.

WHO. 2012. World Health Statistic 2012.

Yang, H.Y., Yang, S.C., Chen, S.T. \& Chen, J.R. 2008. Soy protein hydrolysate ameliorates cardiovascular remodeling in rats with L-NAME-induced hypertension. The Journal of Nutritional Biochemistry 19: 833-839. 
Zainudin, M.M.,Zakaria,Z. \& Nordin, N.A.M.M. 2015. The use of Piper sarmentosum leaves aqueous extract (Kadukmy ${ }^{\mathrm{TM}}$ ) as antihypertensive agent in spontaneous hypertensive rats. BMC Complementary and Alternative Medicine 15: 54.

Zakaria,Z., Patahuddin, H., Mohamad, A., Israf, D.\& Sulaiman, M. 2010. In vivo anti-nociceptive and anti-inflammatory activities of the aqueous extract of the leaves of Piper sarmentosum. Journal of Ethnopharmacology 128: 42-48.

Nik Aloesnisa Nik Mohd Alwi,Zaiton Zakaria, Nor Anita Megat Mohd Nordin \& Azizah Ugusman*

Department of Physiology, Faculty of Medicine Universiti Kebangsaan Malaysia Medical Centre Jalan Yaacob Latiff, Bandar Tun Razak, Cheras 56000 Kuala Lumpur, Federal Territory

Malaysia
Aminuddin Abdul Hamid Karim

Physiology Unit

Universiti Pertahanan Nasional Malaysia

57000 Kuala Lumpur, Federal Territory

Malaysia

Nik Aloesnisa Nik Mohd Alwi

Basic Science and Oral Biology Unit

School of Dental Sciences

Universiti Sains Malaysia

16150 Kubang Kerian, Kelantan Darul Naim

Malaysia

*Corresponding author; email: dr.azizah@ppukm.ukm.edu.my

Received: 25 March 2018

Accepted: 6 June 2018 